\title{
A new insight into isotopic fractionation associated with decarboxylation in organisms: implications for amino acid isotope approaches in biogeoscience
}

\author{
Yuko Takizawa ${ }^{1 *}$ (D), Yoshinori Takano ${ }^{2}$, Bohyung Choi ${ }^{1,3,4}$, Prarthana S. Dharampal ${ }^{5}$, Shawn A. Steffan ${ }^{5,6}$,
} Nanako O. Ogawa ${ }^{2}$, Naohiko Ohkouchi ${ }^{2}$ and Yoshito Chikaraishi, ${ }^{1,2}$

\begin{abstract}
Stable nitrogen $\left({ }^{15} \mathrm{~N} /{ }^{14} \mathrm{~N}\right)$ and carbon $\left({ }^{13} \mathrm{C} /{ }^{12} \mathrm{C}\right)$ isotopic compositions of amino acids in organisms have widely been employed as a powerful tool to evaluate resource utilization and trophic connection among organisms in diverse ecosystems. However, little is known about the physiological factors or mechanisms responsible for determining the isotopic discrimination (particularly for carbon) within amino acids of organisms. In the present study, we investigated the inter-trophic discrimination of nitrogen and carbon isotopes within amino acids $\left(\Delta \delta^{15} N_{A A}\right.$ and $\Delta \delta^{13} C_{A A}$, respectively) using four consumer-diet pairs. Each pairing illustrates a metabolic perspective of isotopic fractionation of amino acids. The $\Delta \delta^{15} \mathrm{~N}_{\mathrm{AA}}$ values in these combinations reveal a trend consistent with those observed in many other combinations in previous studies. This further validates a standard scenario: the deamination preferentially removes ${ }^{14} \mathrm{~N}$ amino group from diet-derived amino acids, leaving behind the ${ }^{15} \mathrm{~N}$ enriched amino acids in consumer biomass. The $\Delta \delta^{15} \mathrm{~N}_{\mathrm{AA}}$ values thus mirror the activity of amino acid deamination in consumers. In contrast, the trends in the $\Delta \delta^{13} C_{\mathrm{AA}}$ value suggest a different metabolic fate for the amino acid carbon isotope. Based on our results, we predict the following scenario: decarboxylation preferentially removes ${ }^{12} \mathrm{C}$ a-carbon (i.e., carbonyl-carbon) from pyruvic acid in glycolysis, and from a-ketoglutaric acid in the tricarboxylic acid cycle, leaving behind the ${ }^{13} \mathrm{C}$-enriched both pyruvic and $a$-ketoglutaric acids. The ${ }^{13} \mathrm{C}$ is then transferred to amino acids that are synthesized from the ${ }^{13} \mathrm{C}$-enriched precursor molecules within consumers. The $\Delta \delta^{13} C_{A A}$ values therefore mirror the pathways of de novo amino acid synthesis in consumers. The proposed link between nitrogen and carbon isotopes can refine our knowledge of the potential processes affecting the isotopic fractionation within diet and consumer compartments, as well as environmental samples.
\end{abstract}

Keywords: Compound-specific isotope analysis, Amino acids, Nitrogen, Carbon, Trophic discrimination, Deamination, Decarboxylation, Degradation, Synthesis, Isotope physiology

\footnotetext{
* Correspondence: takizaway@lowtem.hokudai.ac.jp

${ }^{1}$ Institute of Low Temperature Science, Hokkaido University, Sapporo, Japan

Full list of author information is available at the end of the article
}

\section{Springer Open}

() The Author(s). 2020 Open Access This article is licensed under a Creative Commons Attribution 4.0 International License, which permits use, sharing, adaptation, distribution and reproduction in any medium or format, as long as you give appropriate credit to the original author(s) and the source, provide a link to the Creative Commons licence, and indicate if changes were made. The images or other third party material in this article are included in the article's Creative Commons licence, unless indicated otherwise in a credit line to the material. If material is not included in the article's Creative Commons licence and your intended use is not permitted by statutory regulation or exceeds the permitted use, you will need to obtain permission directly from the copyright holder. To view a copy of this licence, visit http://creativecommons.org/licenses/by/4.0/. 


\section{Definition and Equations}

$\delta^{15} \mathrm{~N}$, stable isotopic composition of nitrogen;

$$
\delta^{15} \mathrm{~N}(\text { permil })=\left(\left({ }^{15} \mathrm{~N} /{ }^{14} \mathrm{~N}_{\text {Sample }}\right) /\left({ }^{15} \mathrm{~N} /{ }^{14} \mathrm{~N}_{\mathrm{AIR}}\right)-1\right) \times 1000
$$

$\delta^{13} \mathrm{C}$, stable isotopic composition of carbon;

$$
\delta^{13} \mathrm{C}(\text { permil })=\left(\left({ }^{13} \mathrm{C} /{ }^{12} \mathrm{C}_{\text {Sample }}\right) /\left({ }^{13} \mathrm{C} /{ }^{12} \mathrm{C}_{\mathrm{VPDB}}\right)-1\right) \times 1000
$$

\section{Introduction}

During the past four decades, the analysis of stable isotope ratios (e.g., ${ }^{15} \mathrm{~N} /{ }^{14} \mathrm{~N},{ }^{13} \mathrm{C} /{ }^{12} \mathrm{C}$ ) has been used widely in the study of biogeosciences (e.g., Fry 2006). While DNA analysis can visualize the biosphere in terms of species through genetic profiles, isotope analysis can visualize the biosphere in terms of the quantitative flux in physical and/or biochemical processes (e.g., CarreonMartinez and Heath 2010; Maeda et al. 2012; Traugott et al. 2013). Isotopic discrimination is frequently quantified by the kinetic isotope effect $(\alpha)$ and flux $(F)$ of the processes (e.g., Hoering 1957; Mariotti et al. 1981; Goto et al. 2018). The wide array of biochemical reactions within organisms creates diverse and distinctive isotopic compositions within the biosphere $\left(\delta^{15} \mathrm{~N}\right.$, \%o vs. atmospheric nitrogen gas [AIR]; $\delta^{13} \mathrm{C}, \%$ vs. Vienna Peedee Belemnite [VPDB]). Often, these stable isotopic compositions represent discernible ratios and thus can be useful for characterizing and quantifying any given process in the biosphere (e.g., Hayes 2001; Chikaraishi 2014; Ohkouchi et al. 2015). Identification of key processes driving isotopic fractionation $(\varepsilon)$ is therefore indispensable for a fundamental understanding of "universality" of the isotopic discrimination $\left(\Delta=\delta_{\mathrm{A}}-\delta_{\mathrm{B}}\right.$; where organism $\mathrm{A}$ is consumer and B is diet), as well as for validating the accuracy and precision of isotopic evidence in application studies (e.g., Hayes 2001; Wada et al. 2013; Ohkouchi et al. 2015).

Nitrogen isotopes with amino acids undergo varying degrees of isotopic discrimination $\left(\Delta \delta^{15} \mathrm{~N}_{\mathrm{AA}}\right)$ during trophic transfer (e.g., Gaebler et al. 1963, 1966; Hare et al. 1991; McClelland and Montoya 2002; Chikaraishi et al. 2007; McCarthy et al. 2007; Popp et al. 2007; Steffan et al. 2015; McMahon and McCarthy 2016; Ishikawa 2018). The patterns of $\Delta \delta^{15} \mathrm{~N}_{\mathrm{AA}}$ values have been frequently associated with the trophic tendencies and amino acid degradation pathways within organisms (Takizawa and Chikaraishi 2014, 2017; Takizawa et al. 2017; Choi et al. 2018; Goto et al. 2018). Chikaraishi et al. (2007) proposed that deamination (preceding transamination) is a key process for isotopic fractionation of nitrogen within amino acids, which preferentially removes the ${ }^{14} \mathrm{~N}$ amino group of diet-derived amino acids and leaves behind ${ }^{15} \mathrm{~N}$ (by up to $\sim 3-8 \%$ o per trophic transfer) in the residual pool of amino acids in consumer biomass. The degree of deamination activity, therefore, results in a great diversity in the isotopic discrimination-large values for some amino acids (e.g., alanine, valine, isoleucine, proline, and glutamic acid) and small values for some other amino acids (e.g., methionine and phenylalanine) between consumer and diet-resource species, as shown in ${ }^{15} \mathrm{~N}$-enrichment factors (Chikaraishi et al. 2009). These two groups of amino acids are frequently called "trophic" and "source" amino acids, respectively (e.g., Popp et al. 2007; reviewed in Ohkouchi et al. 2017). Using this framework, the $\delta^{15} \mathrm{~N}$ analysis of amino acids has rapidly evolved into a unified approach: the $\delta^{15} \mathrm{~N}$ values of the source amino acids in organisms directly provide the $\delta^{15} \mathrm{~N}$ values of primary producers at bases of food webs, whereas difference in the $\Delta \delta^{15} \mathrm{~N}_{\mathrm{AA}}$ value between trophic and source amino acids within a single organism correlates with its position in the trophic hierarchy (e.g., Chikaraishi et al. 2009; Steffan et al. 2013; Chikaraishi et al. 2014; Broek and McCarthy 2015; Choy et al. 2015; Lorrain et al. 2015; Blanke et al. 2017; Choi et al. 2017; Dharampal and Findlay 2017; Steffan et al. 2017; Ostrom et al. 2017; Blanke et al. 2018; Morra et al. 2019).

The large diversity in the carbon isotopic composition of amino acids $\left(\delta^{13} \mathrm{C}_{\mathrm{AA}}\right)$ has been useful in describing metabolic and trophic interactions (e.g., Abelson and Hoering 1961; Macko et al. 1987; Ostrom et al. 1994; Fantle et al. 1999; O'Brien et al. 2002; McCarthy et al. 2004; Larsen et al. 2009, 2013; McMahon et al. 2010, 2015; Fry et al. 2018; Takano et al. 2018). Trophic discrimination of carbon isotopes within amino acids $\left(\Delta \delta^{13} \mathrm{C}_{\mathrm{AA}}\right)$ is reportedly small or negligible for aromatic (e.g., phenylalanine) and branched-chain amino acids (e.g., valine, leucine, and isoleucine), but can vary widely between $-10 \%$ and $+10 \%$ o for other amino acids (e.g., glycine, alanine, aspartic acid, proline, and glutamic acid) (Fantle et al. 1999; Howland et al. 2003; McMahon et al. 2010, 2015). Although there is little knowledge regarding the key metabolic processes responsible for the observed $\Delta \delta{ }^{13} \mathrm{C}_{\mathrm{AA}}$ values (Hayes 2001; Takano et al. 2018), these two types of amino acids are not consistent with the "trophic" and "source" classification of amino acid nitrogen isotopes. Based on this dichotomy, it has been suggested that the limited amounts of de novo synthesis of essential amino acids caused the lower values of $\Delta \delta^{13} \mathrm{C}_{\mathrm{AA}}$. Conversely, the large variation in the $\Delta \delta^{13} \mathrm{C}_{\mathrm{AA}}$ value for nonessential amino acids is attributed to frequent de novo synthesis reactions and/or metabolic routing from dietary substrates such as proteins, fats, and carbohydrates (PFC) in consumers (Fantle et al. 1999; O’Brien et al. 2002, 2005; McMahon et al. 2010; Choy et al. 2013; McMahon et al. 2015). These findings provide a framework in which the $\delta^{13} \mathrm{C}$ values of essential amino acids can potentially serve as a "finger- 
printing" tool to trace the trophic legacy of carbon from diverse dietary resources (e.g., phytoplankton, macroalgae, bacteria, and fungi) to consumer compartments (e.g., Larsen et al. 2009, 2013, 2015; McMahon et al. 2010, 2016). The identification of the key processes in organisms thus will be required for better understanding of the metabolic underpinnings of isotope ecology.

In the present study, we determined the $\Delta \delta^{15} \mathrm{~N}_{\mathrm{AA}}$ and $\Delta \delta^{13} \mathrm{C}_{\mathrm{AA}}$ values together with the concentration and molar balance of amino acids in four pairs of consumerdiet invertebrates: (1) sea slug-sponge (collected from a coastal marine ecosystem), (2) ladybug beetle-aphid (collected from a terrestrial ecosystem), (3) green lacewing-fall armyworm, and (4) green lacewing-green lacewing (reared in laboratory-controlled feeding experiments). These consumer-diet pairings allow for empirical measurement of inter-trophic discrimination factor (inter-TDF) for the nitrogen and carbon isotopes (i.e., $\Delta \delta^{15} \mathrm{~N}_{\mathrm{AA}}$ and $\Delta \delta^{13} \mathrm{C}_{\mathrm{AA}}$, respectively) in a single trophic transfer, and in the process provides a mechanistic model of the isotopic fractionation processes affecting the inter-TDF of amino acids.

\section{Materials and Methods}

\subsection{Natural consumer-diet combinations}

The sea slug Hypselodoris festiva and the sponge Halichondria okadai were collected in May 2016, from a stony shore in Yugawara $\left(35.080^{\circ} \mathrm{N}, 139.070^{\circ} \mathrm{E}\right)$, Japan. $H$. festiva is monophagous on $H$. okadai (e.g., Watanabe et al. 2009). Since H. okadai is ubiquitous on near-shore stones all year, $H$. festiva was able to feed on this diet year-round. One individual of $H$. festiva and one aggregation (ca. $20 \mathrm{~mm} \times 50 \mathrm{~mm}$ ) of $H$. okadai were collected, dried, and homogenized for the isotope analysis. We note that we did not find other individuals for $H$. festiva at the sampling.

Larvae of the ladybug beetle Menochilus sexmaculatus and larvae of the aphid Aphidoidea sp. were collected in September 2014, from a shrub at a house-garden in Yugawara $\left(35.152^{\circ} \mathrm{N}, 139.118^{\circ} \mathrm{E}\right)$, Japan. M. sexmaculatus is aphidophagous in both larval and adult stages (e.g., Khan and Khan 2002), and the larvae of M. sexmaculatus collected in the present study were able to feed only on a single species of the aphid, Aphidoidea sp., within a small shrub habitat. Five individuals of $M$. sexmaculatus and a colony of approximately fifty Aphidoidea sp. were collected, dried, and homogenized for the isotope analysis.

\subsection{Reared consumer-diet combinations}

The controlled feeding experiments for the two combinations: green lacewing (Chrysoperla rufilabris)-fall armyworm (Spodoptera frugiperda) and C. rufilabris-C. rufilabris were conducted in Steffan et al. (2013). Briefly,
S. frugiperda larvae were cultured on a single isotopically homogeneous diet and frozen to serve as prey for the $C$. rufilabris larvae. Then, a subset of the $C$. rufilabris larvae were frozen and used for prey for the remaining C. rufilabris larvae. Four of each trophic group (including 4-8 individuals for each trophic group) were used for the analysis. The $\delta^{15} \mathrm{~N}$ values of amino acids were reported in Steffan et al. (2013).

\subsection{Analysis of nitrogen and carbon isotopic compositions in amino acids}

All samples were prepared for the isotope analysis after $\mathrm{HCl}$ hydrolysis and $\mathrm{N}$-pivaloyl/isopropyl ( $\mathrm{Pv} / \mathrm{iPr}$ ) derivatization, according to the procedure in Chikaraishi et al. (2009). The Pv/iPr derivatization was used for both nitrogen and carbon isotope analysis. However, for carbon isotope analysis, care was taken to keep reaction balance of pivaloyl chloride to dried sample $(75 \mu \mathrm{l} / \mathrm{mg})$.

The molar and isotopic compositions of amino acid derivatives were determined by gas chromatography/isotope ratio mass spectrometry (GC/IRMS) using a $6890 \mathrm{~N}$ GC (Agilent Technologies) instrument coupled to a Delta ${ }^{\text {plus } X P ~ I R M S ~ i n s t r u m e n t ~ t h r o u g h ~ c o m b u s t i o n ~}\left(950^{\circ} \mathrm{C}\right)$ and reduction $\left(550^{\circ} \mathrm{C}\right)$ furnaces and a countercurrent dryer $\left(\right.$ Nafion $^{\mathrm{TM}}$ ) via a GC-C/TC III interface (Thermo Fisher Scientific). An HP Ultra-2 capillary column (50 m; i.d. $0.32 \mathrm{~mm}$; film thickness $0.52 \mu \mathrm{m}$; Agilent Technologies) was used for chromatographic separation of amino acids. For nitrogen isotope analysis, a liquid nitrogen $\mathrm{CO}_{2}$ trap was installed between reduction and countercurrent dryer, because the generated $\mathrm{CO}_{2}$ in the combustion furnace was eliminated and the generated $\mathrm{N}_{2}$ was injected to the IRMS instrument. In contrast, for carbon isotope analysis, a liquid nitrogen $\mathrm{CO}_{2}$ trap was not installed, and the generated $\mathrm{CO}_{2}$ was injected to the IRMS instrument.

For both nitrogen and carbon, the combination of sea slug-sponge and ladybug beetle-aphid was analyzed by triplicate injections for each sample, and the combination of green lacewing-fall armyworm and green lacewing-green lacewing was analyzed by a single injection for each of four trophic groups. The $\delta^{15} \mathrm{~N}$ and $\delta^{13} \mathrm{C}$ values of amino acid derivatives were obtained as the mean $\pm 1 \sigma$, in the triplicate injections for sea slugsponge and ladybug beetle-aphid or in the four trophic groups for green lacewing-fall armyworm and green lacewing-green lacewing combinations. To assess the reproducibility of the isotope measurement, an isotopic reference mixture of amino acids (Indiana University; Shoko Science Co.) was analyzed after every five or six sample runs, with three pulses of reference $\mathrm{N}_{2}$ or $\mathrm{CO}_{2}$ gas discharged at the beginning and end of each run. The $\delta^{15} \mathrm{~N}$ and $\delta^{13} \mathrm{C}$ values were expressed relative to the isotopic compositions of AIR and VPDB, respectively, on 
scales normalized to known $\delta$ values of the reference amino acids. Analytical errors for the reference mixtures were $0.3-0.6 \%$ o ( $1 \sigma$ for replication) for the $\delta^{15} \mathrm{~N}$ values, and $0.7-1.4 \%$ ( $1 \sigma$ for replication) for the $\delta^{13} \mathrm{C}$ values.

\subsection{Calculation for $\Delta \delta^{15} \mathrm{~N}$ and $\Delta \delta^{13} \mathrm{C}$ in amino acids}

The discrimination of nitrogen isotopes $\left(\Delta \delta^{15} \mathrm{~N}\right)$ of amino acids in each consumer-diet combination was calculated by the Eq. (1), because no artificial isotopic fractionation $\left(\varepsilon_{\mathrm{a}}\right)$ is found in experimental procedures (including derivatization) for nitrogen isotopes.

$$
\Delta \delta^{15} \mathrm{~N}_{\mathrm{A}-\mathrm{B}}=\delta^{15} \mathrm{~N}_{\mathrm{m}, \mathrm{A}}-\delta^{15} \mathrm{~N}_{\mathrm{m}, \mathrm{B}}
$$

where $\delta^{15} \mathrm{~N}_{\mathrm{m}}$ indicates the measured $\delta^{15} \mathrm{~N}$ value of a $\mathrm{Pv} / \mathrm{iPr}$ amino acid derivative. On the other hand, the discrimination of carbon isotopes $\left(\Delta \delta^{13} C\right)$ of amino acids was calculated by Eqs. (2) and (3), because artificial isotopic fractionation $\left(\varepsilon_{\mathrm{a}}\right)$ is considerably large in the experimental procedures (especially for the acylation) for carbon isotopes. The isotopic mass balance equation for the $\delta^{13} \mathrm{C}$ value of an amino acid was given by:

$$
n_{o} \times \delta^{13} \mathrm{C}_{\mathrm{o}}=\left(n_{o}+n_{d}\right) \times \delta^{13} \mathrm{C}_{\mathrm{m}}-n_{d} \times\left(\delta^{13} \mathrm{C}_{\mathrm{d}}-\varepsilon_{a}\right)
$$

where $\delta^{13} \mathrm{C}_{\mathrm{m}}$ and $\delta^{13} \mathrm{C}_{\mathrm{o}}$ indicate the measured and original $\delta^{13} \mathrm{C}$ values of an amino acid, respectively; $\delta^{13} \mathrm{C}_{\mathrm{d}}$ and $\varepsilon_{\mathrm{a}}$ indicate the $\delta^{13} \mathrm{C}$ value of derivative groups and artificial isotopic fractionation during derivatization, respectively; and $n_{\mathrm{o}}$ and $n_{\mathrm{d}}$ indicate the number of carbon atoms in an amino acid (e.g., two $\mathrm{C}$ atoms in glycine) and the derivative groups (e.g., eight $\mathrm{C}$ atoms in $\mathrm{Pv} / \mathrm{iPr}$ glycine), respectively. The $\Delta \delta^{13} \mathrm{C}$ value was given by:

$$
\begin{aligned}
\Delta \delta^{13} \mathrm{C}_{\mathrm{A}-\mathrm{B}} & =\left(\delta^{13} \mathrm{C}_{\mathrm{o}, \mathrm{A}}-\delta^{13} \mathrm{C}_{\mathrm{o}, \mathrm{B}}\right) \\
& =\left[\left(n_{o}+n_{d}\right) / n_{o}\right] \times\left(\delta^{13} \mathrm{C}_{\mathrm{m}, \mathrm{A}}-\delta^{13} \mathrm{C}_{\mathrm{m}, \mathrm{B}}\right)
\end{aligned}
$$

Although the $\delta^{13} \mathrm{C}_{\mathrm{o}}$ values were not determined in the present study, the $\Delta \delta^{13} \mathrm{C}$ values were thus obtained by Eq. (3).

The $\Delta \delta^{15} \mathrm{~N}$ and $\Delta \delta^{13} \mathrm{C}$ values were reported for seven amino acids (i.e., phenylalanine, valine, leucine, isoleucine, glycine, alanine, and glutamic acid) in the present study, because baseline separation for each peak of the amino acids was observed for these seven amino acids but not for the other amino acids (e.g., aspartic acid, proline, serine, and threonine) on the GC/IRMS chromatogram.

\section{Results}

\subsection{Concentration and molar balance of amino acids}

Concentration of each amino acid and molar balance among these amino acids was determined based on $\mathrm{m} / \mathrm{z} 28$ peak area of chromatograms (Table 1, Fig. 1).
No substantial difference in the molar balance and concentration (weight \% for total of 7 detected amino acids) is found between consumers and their diets in a given combination. We found that the molar balance in the sea slug-sponge combination is different from that in the other combinations. The former combination has a small abundance of phenylalanine $(\sim 6.5 \%)$ and a high abundance of glycine $(\sim 30 \%)$, whereas the latter combinations have a small abundance of phenylalanine (6.4-9.6\%) and a high abundance of glutamic acid ( 29\%). No substantial difference (i.e., $5.2 \%$ in maximum) in the molar balance is found within a single combination, which is much smaller than the analytical error (10\%) for the molar quantification of amino acids in the present study.

\section{2 $\Delta \delta^{15} \mathrm{~N}$ and $\Delta \delta^{13} \mathrm{C}$ of amino acids}

The $\Delta \delta^{15} \mathrm{~N}_{\mathrm{AA}}$ values in these samples range from $0.3 \%$ (for phenylalanine) to $8.1 \%$ (for glutamic acid), and exhibit a wide diversity in their respective means and variances among the amino acids examined in the four consumer-diet pairs (Table 2, Fig. 2a). There is a low mean value $(0.4 \%)$ with little variation $(0.1 \%$ o as $1 \sigma$ ) for an aromatic amino acid (i.e., phenylalanine), a high mean value (from 4.0 to $5.6 \%$ ) with a little variation (from 0.7 to $1.0 \%$ ) for branched-chain amino acids (i.e., valine, leucine, isoleucine), and a large mean value (from 2.5 to $7.9 \%$ ) with large variation (from 0.2 to $2.8 \%$ ) for the other amino acids (i.e., glycine, alanine, and glutamic acid). Glycine particularly has a unique characteristic for a large variation $(2.8 \%$ o $)$ among the four combinations.

The $\Delta \delta^{13} \mathrm{C}_{\mathrm{AA}}$ values in these samples varies from 1.0 (for valine and leucine) to $17.5 \%$ (for glycine), which is approximately twice as much as the variation in the $\Delta \delta^{15} \mathrm{~N}_{\mathrm{AA}}$ value (Table 2, Fig. 2b). There is a low mean value (from -0.4 to $0.1 \%$ ) with a little variation (from 0.6 to $0.9 \%$ ) for an aromatic (i.e., phenylalanine) and branched-chain (i.e., valine, leucine, and isoleucine) amino acids. On the other hand, there is a broad range of mean value (from 1.7 to $12.4 \%$ ) with variable variation (from 1.1 to $6.8 \%$ ) for the other amino acids (i.e., glycine, alanine, and glutamic acid). The highest mean value $(12.4 \%$ ) with the greatest variation $(6.8 \%)$ is found for glycine among the amino acids examined in the present study.

\section{Discussion}

\subsection{Analytical issues for $\Delta \delta^{13} \mathrm{C}$ of amino acids}

Compound-specific isotope analysis of nitrogen and carbon within amino acids has become pervasive in many 
Table 1 Molar balance of amino acids in the combination samples

\begin{tabular}{|c|c|c|c|c|c|c|c|c|c|c|c|c|c|c|c|c|c|}
\hline \multirow[t]{3}{*}{ Samples } & \multirow[t]{3}{*}{ Scientific name } & \multicolumn{14}{|c|}{ Relative abundance (mol \%) } & \multirow{2}{*}{\multicolumn{2}{|c|}{$\begin{array}{l}\text { Total content } \\
\text { of } 7 \text { amino } \\
\text { acids (wt \%) }\end{array}$}} \\
\hline & & \multicolumn{2}{|l|}{ Phe } & \multicolumn{2}{|l|}{ Val } & \multicolumn{2}{|l|}{ Leu } & \multicolumn{2}{|l|}{ Ile } & \multicolumn{2}{|l|}{ Gly } & \multicolumn{2}{|l|}{ Ala } & \multicolumn{2}{|l|}{ Glu } & & \\
\hline & & Mean & $\mathrm{SD}$ & Mean & SD & Mean & $\mathrm{SD}$ & Mean & $\mathrm{SD}$ & Mean & $\mathrm{SD}$ & Mean & $\mathrm{SD}$ & Mean & SD & Mean & SD \\
\hline \multicolumn{18}{|l|}{ Natural marine samples } \\
\hline Sponge* & Halichondria okadai & 6.4 & 1.4 & 13.1 & 1.5 & 13.2 & 1.3 & 11.6 & 1.7 & 30.1 & 3.5 & 12.5 & 1.4 & 13.1 & 1.7 & 28.4 & 3.5 \\
\hline Sea slug** & Hypselodoris festiva & 6.6 & 0.9 & 13.9 & 0.9 & 12.8 & 2.1 & 11.7 & 1.2 & 29.5 & 1.2 & 13.1 & 1.0 & 12.4 & 2.9 & 28.7 & 2.3 \\
\hline \multicolumn{18}{|l|}{ Natural terrestrial samples } \\
\hline Aphid* & Aphidoidea sp. & 7.4 & 0.9 & 10.2 & 1.2 & 18.3 & 1.9 & 13.8 & 1.5 & 12.7 & 1.3 & 11.0 & 1.2 & 26.6 & 2.7 & 31.8 & 3.0 \\
\hline Ladybug beetle* & $\begin{array}{l}\text { Menochilus } \\
\text { sexmaculatus }\end{array}$ & 9.2 & 0.9 & 9.1 & 0.9 & 21.3 & 2.1 & 11.8 & 1.2 & 11.1 & 1.2 & 9.0 & 1.0 & 28.6 & 2.9 & 34.2 & 2.8 \\
\hline \multicolumn{18}{|l|}{ Reared samples } \\
\hline Fall armyworm*** & $\begin{array}{l}\text { Spodoptera } \\
\text { frugiperda }\end{array}$ & 8.1 & 0.9 & 13.6 & 1.5 & 16.4 & 1.7 & 7.4 & 0.8 & 13.0 & 1.7 & 12.3 & 3.9 & 29.3 & 3.1 & 33.1 & 2.1 \\
\hline Green lacewing \#1*** & $\begin{array}{l}\text { Chrysoperla } \\
\text { rufilabris }\end{array}$ & 6.4 & 0.8 & 11.6 & 1.2 & 17.5 & 1.8 & 8.6 & 0.9 & 12.2 & 1.2 & 15.2 & 1.6 & 28.5 & 2.9 & 34.3 & 3.6 \\
\hline $\begin{array}{l}\text { Green lacewing \#2*** } \\
\text { Chrysoperla rufilabris }\end{array}$ & & 9.6 & 1.5 & 6.4 & 1.2 & 17.2 & 2.1 & 5.9 & 0.8 & 15.9 & 2.3 & 14.7 & 2.0 & 30.3 & 4.1 & 34.5 & 4.2 \\
\hline
\end{tabular}

* SD represents $1 \sigma$ for comparing 3 injections for 1 aggregation (sponge), 1 colony (aphid), and 5 individuals (ladybug beetle)

** SD represents $1 \sigma$ for comparing 3 injections for 1 individual (sea slug)

*** SD represents $1 \sigma$ for comparing 1 injection for each of 3 trophic groups (including 4-7 individuals for each group)

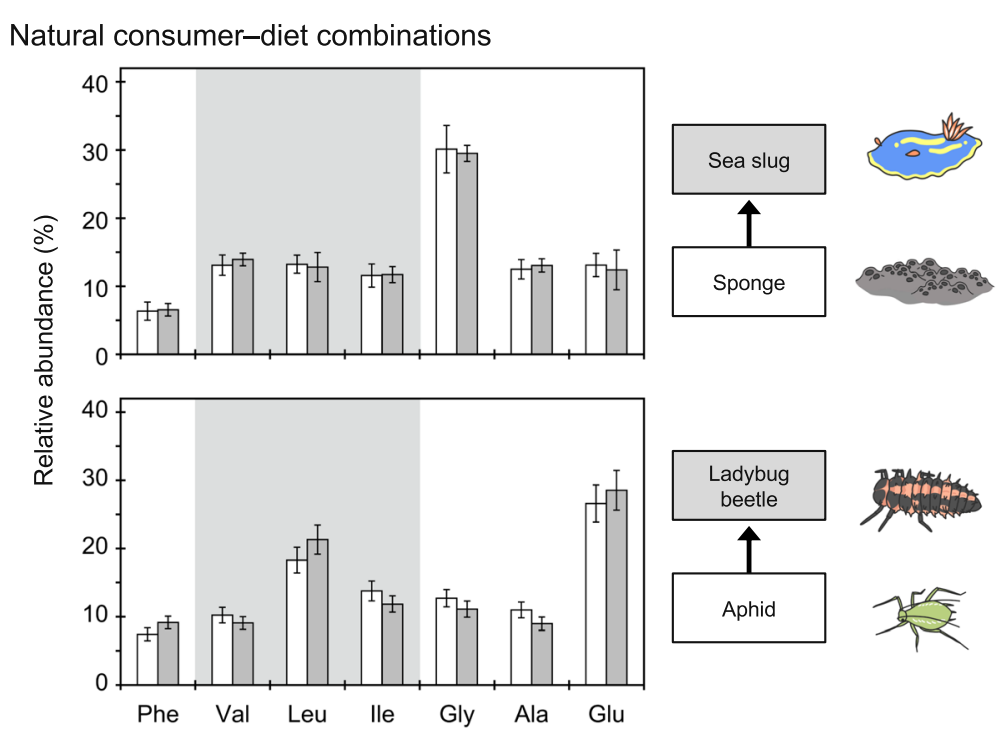

Reared consumer-diet combinations
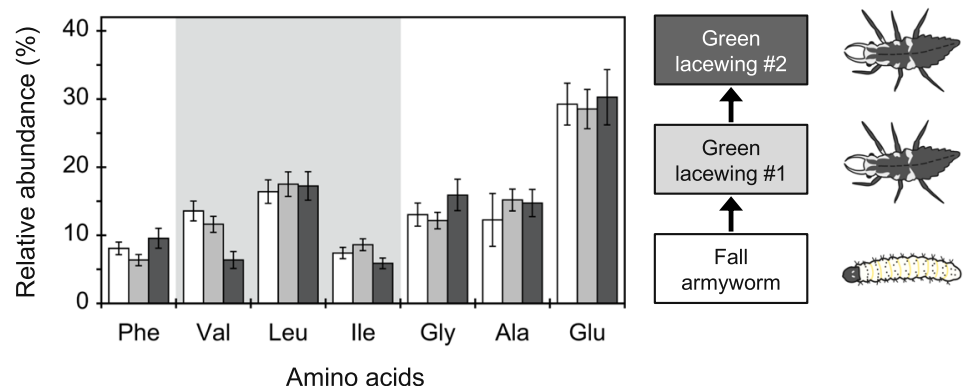

Fig. 1 Molar balance of amino acids for four combinations of consumer and diet. Error bar indicates standard deviation (1 $\sigma)$ of replicate measurements 
Table 2 Nitrogen and carbon isotopic discriminations on amino acids in the four combination samples

\begin{tabular}{|c|c|c|c|c|c|c|c|c|c|c|c|c|c|c|}
\hline \multirow[t]{3}{*}{ Consumer - diet combination } & \multicolumn{14}{|c|}{ 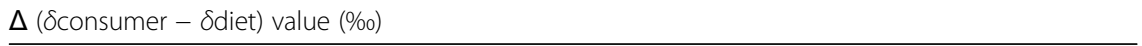 } \\
\hline & \multicolumn{2}{|l|}{ Phe } & \multicolumn{2}{|l|}{ Val } & \multicolumn{2}{|l|}{ Leu } & \multicolumn{2}{|l|}{ Ile } & \multicolumn{2}{|l|}{ Gly } & \multicolumn{2}{|l|}{ Ala } & \multicolumn{2}{|l|}{ Glu } \\
\hline & Mean & SD & Mean & SD & Mean & SD & Mean & SD & Mean & SD & Mean & SD & Mean & SD \\
\hline \multicolumn{15}{|l|}{$\Delta \delta^{15} \mathrm{~N}(\%)$} \\
\hline Sea sulg - Sponge* & 0.5 & 0.3 & 4.8 & 0.6 & 3.0 & 0.6 & 5.6 & 0.4 & 1.6 & 0.6 & 5.5 & 0.6 & 7.9 & 0.3 \\
\hline Ladybug beetle - Aphid** & 0.3 & 0.3 & 6.5 & 0.5 & 5.3 & 0.5 & 3.6 & 0.6 & 6.6 & 0.5 & 4.5 & 0.5 & 7.7 & 0.3 \\
\hline Green lacewing \#1 - Fall armyworm *** & 0.4 & 0.3 & 5.5 & 0.3 & 3.6 & 0.5 & 3.3 & 0.4 & 0.8 & 0.7 & 5.4 & 0.4 & 8.0 & 0.4 \\
\hline Green lacewing \#2 - Green lacewing \#1*** & 0.5 & 0.3 & 5.5 & 0.3 & 4.2 & 0.4 & 3.8 & 0.5 & 0.8 & 0.3 & 5.5 & 0.4 & 8.1 & 0.5 \\
\hline \multicolumn{15}{|l|}{$\Delta \delta^{13} \mathrm{C}(\% 0)$} \\
\hline Sea sulg - Sponge* & -0.3 & 0.8 & 0.0 & 0.7 & 0.4 & 0.7 & 0.4 & 0.9 & 11.9 & 0.6 & 3.9 & 0.4 & 3.5 & 0.5 \\
\hline Ladybug beetle - Aphid** & -0.5 & 0.8 & -1.0 & 0.8 & -1.0 & 0.9 & -0.4 & 0.6 & 3.0 & 1.1 & 4.9 & 0.8 & 2.2 & 0.2 \\
\hline Green lacewing \#1 - Fall armyworm *** & -0.6 & 1.1 & -0.9 & 0.5 & 0.3 & 0.2 & -0.2 & 0.6 & 17.3 & 0.5 & 2.8 & 0.3 & 1.0 & 0.2 \\
\hline Green lacewing \#2 - Green lacewing \#1 *** & 0.2 & 1.1 & 0.3 & 0.9 & -0.5 & 0.5 & 0.5 & 0.9 & 17.5 & 0.7 & 2.6 & 0.4 & 0.2 & 0.9 \\
\hline
\end{tabular}

* SD represents $1 \sigma$ propagation error for comparing $1 \sigma$ of Sea slug (3 injections for 1 individual) and Sponge ( 3 injections for 1 aggregation)

** SD represents $1 \sigma$ propagation error for comparing $1 \sigma$ of Ladybug beetle ( 3 injections for 5 individuals) and Aphid ( 3 injections for 1 colony)

*** SD represents $1 \sigma$ propagation error for comparing $1 \sigma$ of consumer and diet (1 injections for 4 trophic groups)

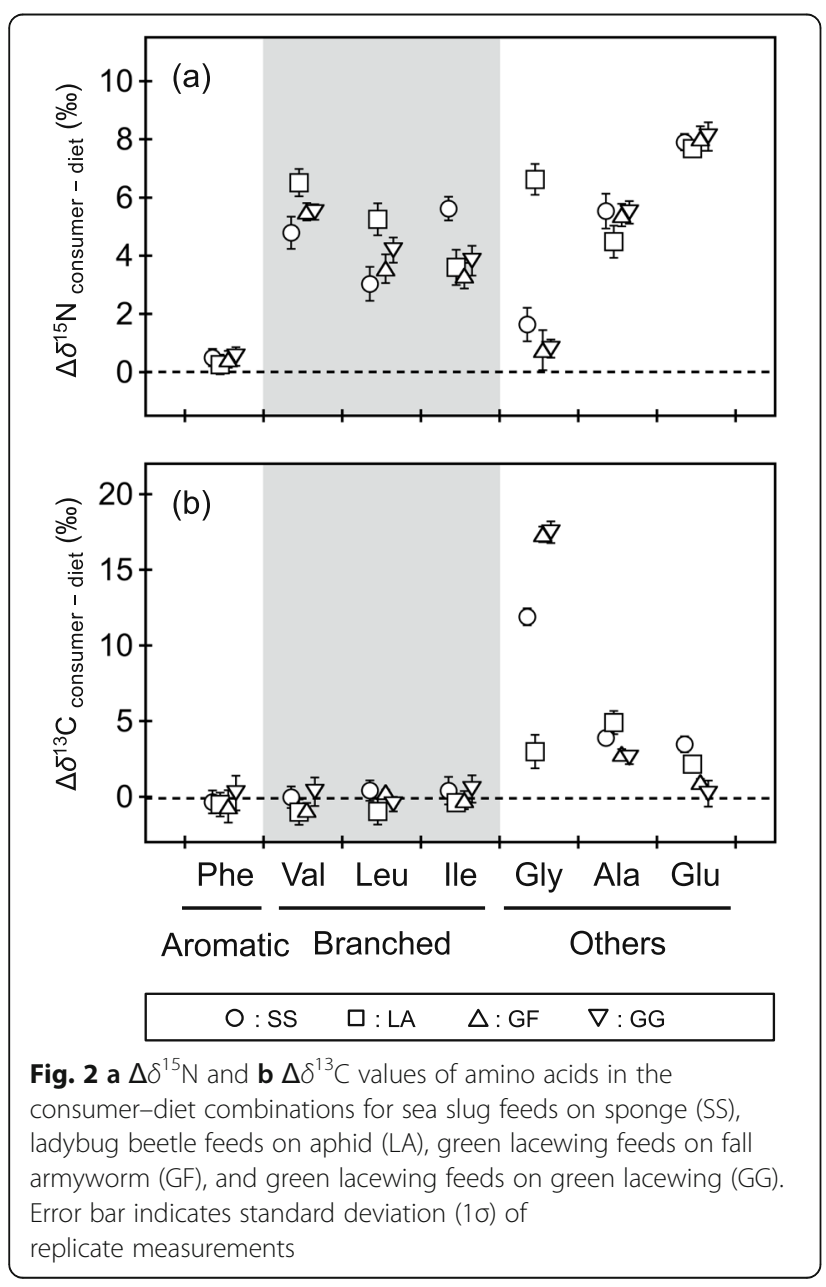

branches of science following the commercial production of the gas chromatograph-isotope ratio mass spectrometer (GC-IRMS) in the 1990s. This system has been carried out via derivatization to neutralize polar carboxyl $(-\mathrm{COOH})$, amino $\left(-\mathrm{NH}_{2}\right)$, and hydroxyl $(-\mathrm{OH})$ groups in amino acids by less-polar moieties prior to the GCIRMS analysis (e.g., Engel et al. 1990; Silfer et al. 1991; Demmelmair and Schmidt 1993; Merritt and Hayes 1994; Metges et al. 1996; Chikaraishi et al. 2010a). However, this technique is still in developmental stages particularly for carbon isotope analysis of amino acids due to associated methodological challenges (e.g., Metges and Daenzer 2000; Docherty et al. 2001; Corr et al. 2007a, 2007b; Chikaraishi and Ohkouchi 2010). During the derivatization, the acylation of the amino group generates an artificial isotopic fractionation $\left(\varepsilon_{\mathrm{a}}\right)$ on the carbonyl-carbon of acyl moiety in the derivatives, because the carbon atom in derivatization reagents bond with amino acids in a non-quantitative reaction (Silfer et al. 1991; Rieley 1994; Metges and Daenzer 2000; Docherty et al. 2001; Chikaraishi and Ohkouchi 2010). This results in three methodological issues: (1) amino acids have large diversity in the structural characteristic (e.g., carbon skeleton, functional group, reaction points, polarity, etc.), resulting in diverse kinetic isotope effects; (2) the $\varepsilon_{\mathrm{a}}$ value are strongly dependent on the molar balance between amino acids and derivative reagents; and (3) the $\varepsilon_{\mathrm{a}}$ values are driven by the molar balance among amino acids, as well as on the sample matrix (particularly the content of hydroxyl groups) (Chikaraishi and Ohkouchi 2010). These issues can cause unreliable determination of the $\delta^{13} \mathrm{C}_{\mathrm{AA}}$ values by GC-IRMS analysis (e.g., Silfer et al. 1991; Chikaraishi and Ohkouchi 2010; Dunn et al. 2011). Even though the issues of isotope effect and molar balance of given amino acids can be 
calculated and controlled (Corr et al. 2007a, 2007b), the control (or correction) of the $\varepsilon_{\mathrm{a}}$ values derived from the contribution of matrix is difficult to ascertain in many cases (Chikaraishi and Ohkouchi 2010). For instance, there is a high dissimilarity in the PFC composition between plants (i.e., cellulose-based) and herbivore (i.e., protein-based) tissues. This results in a large disparity of the $\varepsilon_{\mathrm{a}}$ values for individual amino acids between samples derived from producers and herbivores (Chikaraishi and Ohkouchi 2010; Dunn et al. 2011). To avoid these methodological issues concerning the $\delta^{13} \mathrm{C}_{\mathrm{AA}}$ measurement, we used four carefully selected animal-animal combinations such that the molar balance of amino acids is comparable across consumers and diets, and this was later confirmed by direct quantification (Table 1, Fig. 1). Furthermore, each combination was designed such that the sample matrixes are comparable across diet and consumer compartments. As a result, the uncertainty (i.e., precision) in the $\Delta \delta^{13} \mathrm{C}_{\mathrm{AA}}$ value obtained from the analysis of each combination was better than $0.8-3.3 \%$, the propagation of analytical precision for $\delta^{13} \mathrm{C}$ measurement being $0.7-1.4 \%$.

\subsection{Trophic isotopic discrimination $\left(\Delta \delta^{15} \mathrm{~N}\right.$ and $\left.\Delta \delta^{13} \mathrm{C}\right)$ of amino acids}

Based on the isotopic discriminations observed, the seven amino acids investigated are classified into the following three groups (Fig. 2): (1) no significant fractionation, with near-zero values of both $\Delta \delta^{15} \mathrm{~N}$ and $\Delta \delta^{13} \mathrm{C}$ values for the aromatic amino acid (i.e., phenylalanine); (2) a small positive fractionation of the $\Delta \delta^{15} \mathrm{~N}$ values, but no fractionation of the $\Delta \delta^{13} \mathrm{C}$ values for the branched-chain amino acids (i.e., valine, leucine, and isoleucine); and (3) a large positive fractionation for both $\Delta \delta^{15} \mathrm{~N}$ and $\Delta \delta^{13} \mathrm{C}$ values for the other amino acids (i.e., glycine, alanine, and glutamic acid). Trends in the isotopic discrimination for the first two groups in the present study are consistent with those reported in previous studies (e.g., Chikaraishi et al. 2009; McMahon et al. 2010, 2015; Steffan et al. 2015). On the other hand, we found positive $\Delta \delta^{13} \mathrm{C}$ values in the last group, which is consistent with the values found in McMahon et al. (2015). However, several previous studies reported a broad range of positive and negative values for the $\Delta \delta^{13} \mathrm{C}$ values (e.g., Fantle et al. 1999; Howland et al. 2003; McMahon et al. 2010). Although specific reasons for such conflicting results are unknown, they may be attributed to the methodological issues concerning the carbon isotopic composition of amino acids.

\subsection{Physiological mechanisms for the isotopic discrimination $(\Delta)$}

The kinetic isotopic fractionation $(\varepsilon)$ within organic compounds is principally controlled by the isotope effect $(\alpha)$ and flux $(F)$ of the processes that either form or cleave chemical bonds in metabolic pathways of organisms (e.g., Hoering 1957; Mariotti et al. 1981; Hayes 2001; Chikaraishi 2014; Ohkouchi et al. 2015; Goto et al. 2018). In the case of nitrogen, the $\Delta \delta^{15} \mathrm{~N}_{\mathrm{AA}}$ values in consumer-diet combination can be explained by the activity of deamination for the "source" (e.g., phenylalanine) and "trophic" (e.g., valine, leucine, isoleucine, alanine, and glutamic acid) amino acids, respectively (Fig. 3a) (Chikaraishi et al. 2009, 2010b; Steffan et al. 2015; McMahon and McCarthy 2016; Ohkouchi et al. 2017). Consistency of the $\Delta \delta^{15} \mathrm{~N}_{\mathrm{AA}}$ values between this and previous studies further validates this traditional interpretation.

The $\Delta \delta^{13} \mathrm{C}_{\mathrm{AA}}$ values in consumer-diet combination have been insufficiently understood in previous studies. Four decades ago, DeNiro and Epstein (1977) first demonstrated that metabolic products (i.e., lipids) are greatly depleted in ${ }^{13} \mathrm{C}$ (by 7-8\%) for E. coli cultured with glucose or pyruvic acid, but less depleted in ${ }^{13} \mathrm{C}$ (only by $1 \%$ ) for that with acetate. This suggested that the carbon isotopic fractionation is closely related to the decarboxylation of pyruvic acid to form acetyl-CoA. They further proposed that the decarboxylation of pyruvic acid causes the depletion in ${ }^{13} \mathrm{C}$ at the position of the carbonyl-carbon on acetyl-CoA, likely due to the preferential cleaving of the ${ }^{12} \mathrm{C}-{ }^{12} \mathrm{C}$ bond on the pyruvic acid in the decarboxylation (e.g., Monson and Hayes 1980, 1982; Melzer and Schmidt 1987: Chikaraishi 2014). Based on the findings from prior studies, we propose the following framework (Fig. 3b) to interpret the $\Delta \delta^{13} \mathrm{C}_{\mathrm{AA}}$ values observed in the present study:

(1) The decarboxylation of pyruvic acid (Pyr) in glycolysis preferentially eliminates ${ }^{12} \mathrm{C}$ as acetyl$\mathrm{CoA}$, leaving behind the enriched ${ }^{13} \mathrm{C}$ in the residual pool of pyruvic acid.

(2) Similarly, the decarboxylation of $\alpha$-ketoglutaric acid $(\alpha-\mathrm{Kg})$ in the tricarboxylic acid (TCA) cycle preferentially eliminates ${ }^{12} \mathrm{C}$ as succinyl-CoA (Suc$\mathrm{CoA}$ ), leaving behind the enriched ${ }^{13} \mathrm{C}$ in the residual pool of $\alpha$-ketoglutaric acid.

(3) The enrichment of ${ }^{13} \mathrm{C}$ in the residual pyruvic and $\alpha$ ketoglutaric acids is eventually transferred to amino acids, when the consumers produce the amino acids through de novo synthesis (or metabolic routing) from these ${ }^{13} \mathrm{C}$-enriched residual acids.

According to these processes, the trophic discrimination of carbon isotopes $\left(\Delta \delta^{13} \mathrm{C}\right)$ is not found in "essential" amino acids, where synthetic flux is limited (i.e., phenylalanine, valine, leucine, and isoleucine in the present study). Since decarboxylation in glycolysis and TCA cycle elevates ${ }^{13} \mathrm{C}$ content of the synthetic precursors of amino 


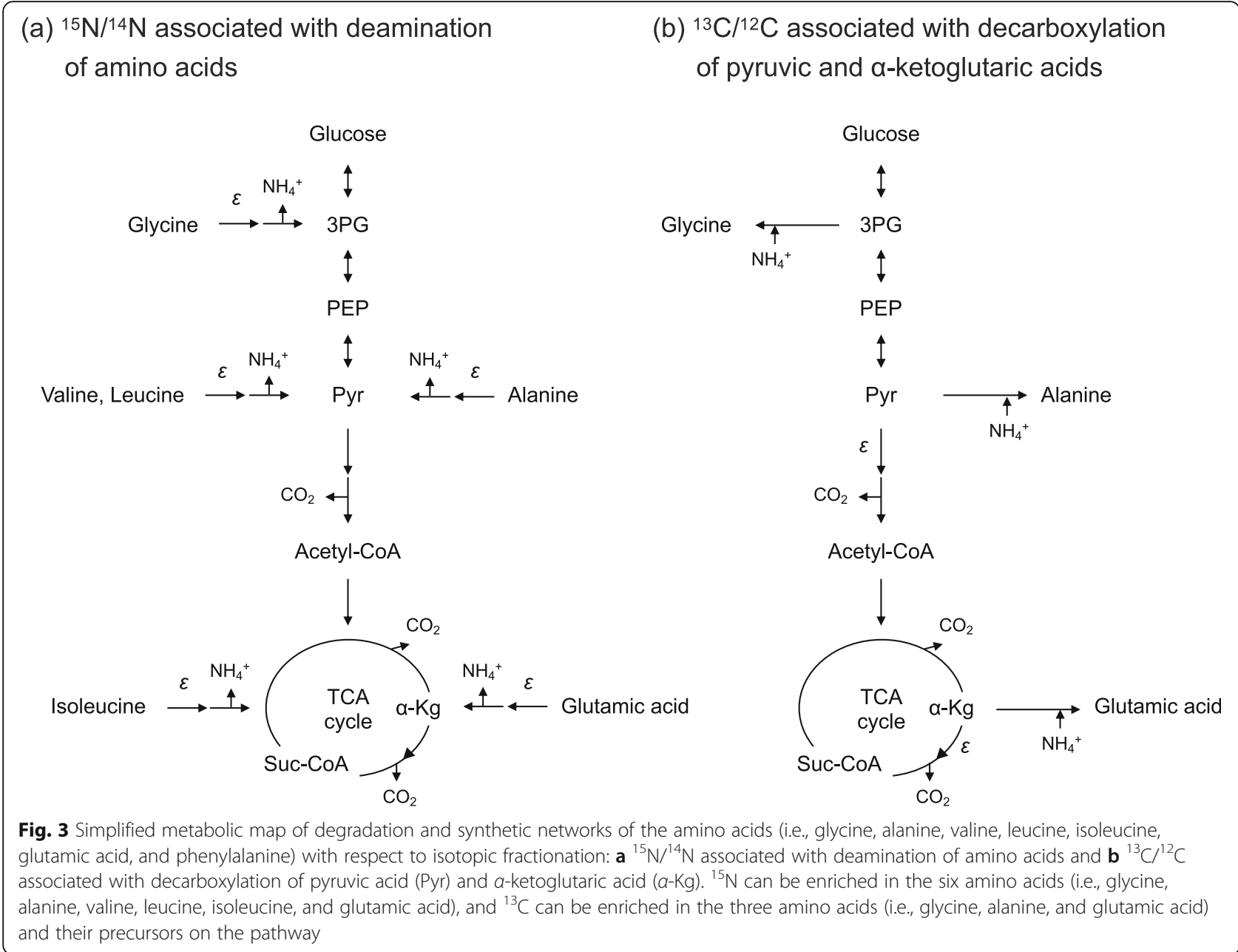

acids, the de novo synthesized nonessential amino acids incorporate the ${ }^{13} \mathrm{C}$ into the newly produced amino acids in consumers, resulting in large $\Delta \delta^{13} \mathrm{C}_{\mathrm{AA}}$ values (i.e., glycine, alanine, and glutamic acid in the present study).

\subsection{Key processes affecting the isotopic fractionation $(\varepsilon)$} From a theoretical perspective, the preferential "cleaving" of chemical bond between light isotopes (i.e., ${ }^{12} \mathrm{C}-{ }^{14} \mathrm{~N}$ ) compared to between light and heavy isotopes (i.e., ${ }^{12} \mathrm{C}-{ }^{15} \mathrm{~N}$ and ${ }^{13} \mathrm{C}-{ }^{14} \mathrm{~N}$ ) of amino acids is the dominant process in the isotopic fractionation of amino acids in metabolic pathways (e.g., Chikaraishi et al. 2007, 2009). This leads to a pattern of simultaneous enrichment in ${ }^{15} \mathrm{~N}$ and ${ }^{13} \mathrm{C}$ associated with deamination of amino acids. However, the results in the present study offer little support to this theoretical consideration and suggest that the $\Delta \delta^{15} \mathrm{~N}_{\mathrm{AA}}$ values are independent of the $\Delta \delta^{13} \mathrm{C}_{\mathrm{AA}}$ values (particularly for branched-chain amino acids) in the studied consumers (Fig. 2). Therefore, we suggest that the isotopic fractionation $(\varepsilon)$ is attributable to the alternative processes that involve the preferential "forming" of the ${ }^{12} \mathrm{C}-{ }^{14} \mathrm{~N}$ or ${ }^{12} \mathrm{C}-{ }^{12} \mathrm{C}$ bond. Indeed, the deamination and decarboxylation initiate the formation of $\mathrm{C}-\mathrm{N}$ and $\mathrm{C}-\mathrm{C}$ bonds between substrate and enzyme, respectively, and ultimately cleave a chemical bond on the substrate. We therefore speculate that the "key" reactions responsible for the isotopic fractionation of amino acids proceeds in the following sequential pattern:

(1) During "forming" of the C-N double bond between an amino acid and pyridoxal phosphate (PLP) at the initial step of deamination, ${ }^{14} \mathrm{~N}$ amino group in amino acids is preferentially bonded and deaminated, and this reaction leaves behind ${ }^{15} \mathrm{~N}$ in the residual pool of amino acids in consumer biomass (Fig. 4a).

(2) During "forming" of the $\mathrm{C}$-C bond between pyruvic acid (or $\alpha$-ketoglutaric acid) and thiamine pyrophosphate (TPP) at the initial step of decarboxylation, the ${ }^{12} \mathrm{C} \alpha$-carbon in pyruvic acid (or $\alpha$ ketoglutaric acid) is preferentially bonded with the TPP and then decarboxylated from the neighboring carboxyl group carbon in pyruvic acid, resulting in that this reaction leaves behind ${ }^{13} \mathrm{C}$ in the residual 
(a) C-N bond forming in deamination<smiles>Cc1ncc(CO)c(C=NF)c1O</smiles><smiles>[R]C([NH3+])C(=O)[O-]</smiles><smiles>[R]C([NH+]=Cc1c(CO)c[nH+]c(C)c1O)C(=O)[O-]</smiles><smiles>Cc1ncc(CO)c(C=[18O])c1O</smiles>

Amino acids<smiles>[R]C(=O)C(=O)[O-]</smiles>

(b) C-C bond forming in decarboxylation

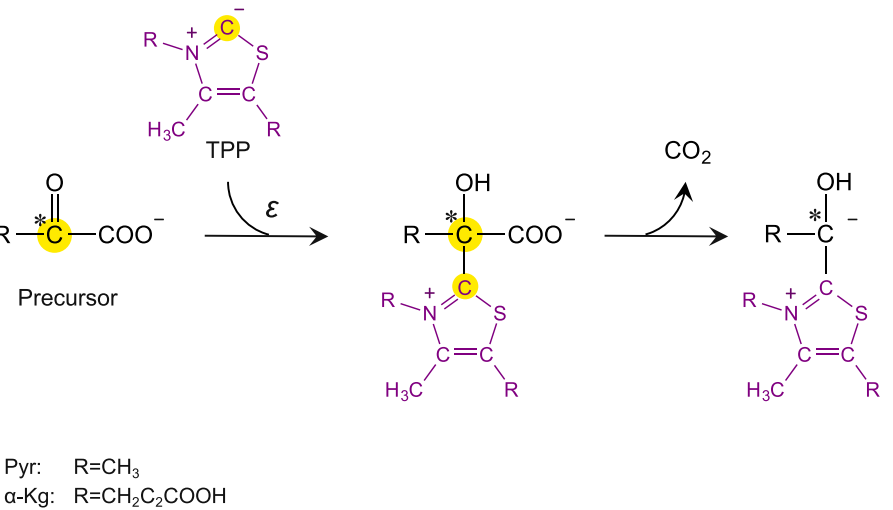

Fig. 4 a Possible scenarios of the isotopic fractionation during deamination of amino acids and $\mathbf{b}$ decarboxylation of pyruvic and $a$-ketoglutaric acids: the fractionation is caused by forming of C-N or C-C bond. Asterisk indicates atoms where isotopic fractionation occurs. Yellow highlight indicates reaction points accompanied with the isotopic fractionation

pool of pyruvic acid (or $\alpha$-ketoglutaric acid) in consumer biomass (Fig. 4b). The enriched ${ }^{13} \mathrm{C}$ can be transferred to those amino acids that are subsequently synthesized de novo by the consumers.

\section{Implications}

Compound-specific isotope analysis of amino acids has been widely used in food web ecology. While nitrogen isotopes have been used to estimate the trophic position (TP) of organisms, carbon isotopes have proven useful in tracing the producers at the foundations of food webs (reviewed in Ohkouchi et al. 2017). However, possible factors for trophic discrimination $(\Delta)$ and key reactions responsible for isotopic fractionation $(\varepsilon)$ of amino acids cannot be sufficiently explained by isotopic fractionation caused by the cleaving of chemical bond. Moreover, artificial isotopic fractionation $\left(\varepsilon_{\mathrm{a}}\right)$ during the derivatization of amino acids increases uncertainty on the $\delta^{13} \mathrm{C}_{\mathrm{AA}}$ value observed.
Through careful selection of consumer-diet pairings, we were able to minimize the methodological error in the $\Delta \delta^{13} \mathrm{C}_{\mathrm{AA}}$ values, and delineate possible factors driving the isotopic discrimination and fractionation of amino acids (Table 3 ). The isotopic fractionation $(\varepsilon)$ can be explained by proposed mechanisms involving the preferential formation of the ${ }^{12} \mathrm{C}-{ }^{14} \mathrm{~N}$ bond (i.e., amino acids with PLP) and ${ }^{12} \mathrm{C}-{ }^{12} \mathrm{C}$ bond (i.e., amino acid precursors with TPP) (Fig. 4). In the case of nitrogen isotopes, although deamination of amino acids is a key reaction (Chikaraishi et al. 2007), the results in the present study further reveal that balance between degradation and synthetic flux is a dominant factor for controlling the trophic isotopic discrimination (Table 3). In the case of carbon isotopes, the results in the present study reveal that decarboxylation of the precursor molecules (e.g., pyruvic and $\alpha$-ketoglutaric acids) is a key reaction, and that the resulting de novo synthetic flux is the dominant factor controlling trophic isotopic 
Table 3 Possible factors for controlling trophic discrimination $(\Delta)$ and key reactions responsible for isotopic fractionation $(\varepsilon)$ on consumers

\begin{tabular}{|c|c|c|c|c|c|}
\hline & \multicolumn{2}{|l|}{ Possible factor for $\Delta$ of an amino acid } & \multicolumn{2}{|c|}{ Key reaction responsible for $\varepsilon$ of an amino acid } & \multirow{2}{*}{$\begin{array}{l}\text { Classification } \\
\text { of amino } \\
\text { acids }\end{array}$} \\
\hline & Nitrogen & Carbon & Nitrogen & Carbon & \\
\hline Aromatic & - & - & - & - & $\begin{array}{l}\text { Source } \\
\text {-Essential }\end{array}$ \\
\hline Branched & Deamination flux of the amino acid & - & $\begin{array}{l}\text { Deamination of } \\
\text { the amino acid }\end{array}$ & - & $\begin{array}{l}\text { Trophic } \\
\text {-Essential }\end{array}$ \\
\hline Others & $\begin{array}{l}\text { Balance between deamination and } \\
\text { biosynthetic flux of the amino acid }\end{array}$ & $\begin{array}{l}\text { Biosynthetic flux of } \\
\text { the amino acid }\end{array}$ & $\begin{array}{l}\text { Deamination of } \\
\text { the amino acid }\end{array}$ & $\begin{array}{l}\text { Decarboxylation of the precursor (e.g., } \\
\text { pyruvic acid and a-ketoglutaric acid) }\end{array}$ & $\begin{array}{l}\text { Trophic } \\
\text {-Nonessential }\end{array}$ \\
\hline
\end{tabular}

discrimination (Table 3). These key reactions form a biochemical intersection of amino acid metabolism, linking the isotope physiology of amino acids in organisms. We use a cross-plot between $\Delta \delta^{15} \mathrm{~N}$ and $\Delta \delta^{13} \mathrm{C}$ to represent this intersection to classify amino acids into three groups (Table 3, Fig. 5):

(1) Source-essential: The aromatic amino acid (i.e., phenylalanine) has the $\Delta \delta^{15} \mathrm{~N}$ and $\Delta \delta^{13} \mathrm{C}$ values very close to zero, due to an absence of both deamination and synthesis activities in consumers (Fig. 5a).

(2) Trophic-essential: The branched-chain amino acids (i.e., valine, leucine, and isoleucine) have high $\Delta \delta^{15} \mathrm{~N}$, but near-zero $\Delta \delta^{13} \mathrm{C}$ values, due to the presence of deamination and an absence of synthesis activities in consumers, respectively (Fig. 5b).

(3) Trophic-nonessential: The other amino acids (i.e., glycine, alanine, and glutamic acid) have an inverse correlation between the $\Delta \delta^{15} \mathrm{~N}_{\mathrm{AA}}$ and $\Delta \delta^{13} \mathrm{C}_{\mathrm{AA}}$ values, due to varying degrees of involvement in deamination and synthesis in consumers (Fig. 5c).

The diversity and variation in the trophic isotopic discrimination among amino acids are closely related to

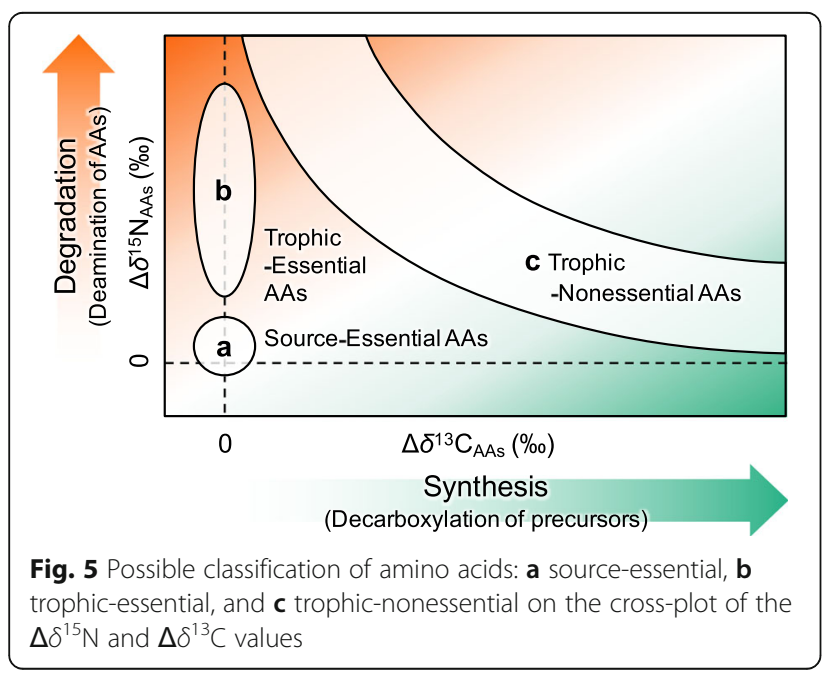

physiological status of organisms. Balance between degradation and synthesis of amino acids shifts based on the energy requirement with respect to environmental conditions such as satiation versus starvation, PFC balance in diets, and life strategy specific to organisms (Germain et al. 2013; Chikaraishi et al. 2015; McMahon et al. 2015; Steffan et al. 2013, 2015; Takizawa et al. 2017; Choi et al. 2018).

The proposed bridged perspective between the $\Delta \delta^{15} \mathrm{~N}_{\mathrm{AA}}$ and $\Delta \delta^{13} \mathrm{C}_{\mathrm{AA}}$ values can reveal the potential processes affecting the isotopic compositions of ecological and environmental samples. While the near-zero values of $\Delta \delta^{13} \mathrm{C}$ of essential amino acids (e.g., phenylalanine, valine, leucine, and isoleucine) have been used to characterize the contribution from basal resources to ecosystems, the broader basis of such empirical data remained largely unknown (Larsen et al. 2009, 2013, 2015; McMahon et al. 2010, 2016). Our findings suggest that such observation arises from the fact that essential amino acids are largely diet-derived, leaving limited scope for the incorporation of decarboxylation-derived ${ }^{13} \mathrm{C}$-enriched precursor molecules (Fig. 2). Additionally, there is little information explaining the idiosyncratic behavior of specific amino acids. For instance, there is a large variation in the $\Delta \delta^{15} \mathrm{~N}$ value of glycine (e.g., $4.0 \pm$ $3.5 \%$ in Chikaraishi et al. 2010b, and $3.9 \pm 4.9$ in McMahon and McCarthy 2016), and the $\Delta \delta^{15} \mathrm{~N}$ values of glutamic acid have been frequently compressed in several animals, particularly for high trophic level consumers that have urea/uric acid cycle (e.g., McMahon and McCarthy 2016). The inverse relationship with respect to $\Delta \delta^{15} \mathrm{~N}_{\mathrm{AA}}$ and $\Delta \delta^{13} \mathrm{C}_{\mathrm{AA}}$ values for trophicnonessential amino acids, glycine, alanine, and glutamic acid, observed in the present study can potentially explain this significantly large variation. Increasing frequency of deaminating reactions expands the $\Delta \delta^{15} \mathrm{~N}_{\mathrm{AA}}$ values, and lowered influx of de novo-synthesized amino acids compresses the $\Delta \delta^{13} \mathrm{C}_{\mathrm{AA}}$ values. Conversely, increased abundance of de novo-synthesized amino acids expands $\Delta \delta^{13} \mathrm{C}_{\mathrm{AA}}$ values, and this is accompanied by the concomitant compression of the $\Delta \delta^{15} \mathrm{~N}_{\mathrm{AA}}$ values. The combined analysis of the $\Delta \delta^{15} \mathrm{~N}$ and $\Delta \delta^{13} \mathrm{C}$ values of 
individual amino acids can thus reflect the metabolic status of consumers and offer a more holistic view of trophic interactions.

The main limitation associated with $\delta^{13} \mathrm{C}_{\mathrm{AA}}$ and $\Delta \delta^{13} \mathrm{C}_{\mathrm{AA}}$ analysis (e.g., Chikaraishi and Ohkouchi 2010) arises from the artificial isotopic fractionation $\left(\varepsilon_{\mathrm{a}}\right.$ in Eqs. 2 and 3) introduced during amino acids derivatization. This methodological challenge has limited the scope of empirical quantification of isotopic fractionation $(\varepsilon)$ associated with "key" processes in metabolism. Continual efforts directed towards method development (e.g., Metges and Daenzer 2000; Docherty et al. 2001; Corr et al. 2007a, 2007b; Smith et al. 2009; Chikaraishi and Ohkouchi 2010) will improve the utility of amino acid isotope approaches in the biogeoscience.

\section{Abbreviations}

AA: Amino acid; DNA: Deoxyribonucleic acid; AIR: Atmospheric nitrogen; PV/ iPr derivatization: Pivaloyl/isopropyl derivatization; GC/IRMS: Gas chromatography/isotope ratio mass spectrometry; GC-IRMS: Gas chromatograph-isotope ratio mass spectrometer; VPDB: Vienna Peedee Belemnite; SS: Sea slug-sponge; LA: Ladybug beetle-aphid; GF: Green lacewing-fall armyworm; GG: Green lacewing-green lacewing; PFC: Proteinfat-carbohydrate; Pyr: Pyruvic acid; 3PG: 3-Phosphoglyceric acid; PEP: Phosphoenolpyruvic acid; a-Kg: a-Ketoglutaric acid; Suc-CoA: SuccinylCoA; PLP: Pyridoxal phosphate; TCA: Tricarboxylic acid; TPP: Thiamine pyrophosphate

\section{Acknowledgements}

We greatly appreciate Dr. Eitaro Wada for his lectures, expert comments/ advices, and constructive discussion, which deconvoluted complex issues in the study of stable isotope physiology and ecology. We also appreciate Dr. Naoto F. Ishikawa (JAMSTEC), Prof. Rong Fan (Northwest University), and Mr. Daochao Xing (Hokkaido University) for the discussion of isotope ratios in amino acids and those ecological aspects. Two anonymous reviewers are greatly acknowledged for improving the manuscript. We thank to the young researcher travel grant (Y. Takizawa) of the Biogeoscience section (FY2017) in Japan Geoscience Union (JpGU), which gave us an opportunity to write this paper in Progress in Earth and Planetary Science.

\section{Authors' contributions}

Y.Takizawa, Y.Takano, and Y.C. conceived the present study. Y.C. collected natural samples and S.A.S. provided reared samples. The manuscript was written primarily by Y.Takizawa with contribution from Y.C., B.C., P.S.D., S.A.S., Y.Takano, N.O., and N.O.O. Y.Takizawa and Y.C prepared and analyzed amino acid derivatives. The authors read and approved the final manuscript.

\section{Funding}

This work was supported by JSPS KAKENHI Grant Number JP $16 J 01704$ to Y. Takizawa, Grant-in-Aid for Scientific Research of the JSPS to Y. Chikaraishi (No. 17H02988), Y. Takano (No. 16H04083), and N. Ohkouchi (No. 16H02236), USDA-ARS appropriated funds to S.A. Steffan, as well as funds from Silicone Industry Association of Japan to Y. Chikaraishi.

\section{Availability of data and materials}

The data for this paper are tabulated in this manuscript.

\section{Competing interests}

We have no conflicts of interests and all authors have seen this manuscript and agree to this submission.

\section{Author details}

'Institute of Low Temperature Science, Hokkaido University, Sapporo, Japan. ${ }^{2}$ Biogeochemistry Research Center (BGC), Japan Agency for Marine-Earth Science and Technology, Yokosuka, Japan. ${ }^{3}$ Department of Marine Sciences and Convergent Technology, Hanyang University, Ansan, Republic of Korea. ${ }^{4}$ Fisheries Science Institute, Chonnam University, Yeosu, Republic of Korea.
${ }^{5}$ Department of Entomology, University of Wisconsin, Madison, WI, USA. ${ }^{6}$ US Department of Agriculture, Agricultural Research Service, Madison, WI, USA.

Received: 3 April 2020 Accepted: 19 August 2020

Published online: 14 September 2020

\section{References}

Abelson PH, Hoering TC (1961) Carbon isotope fractionation in formation of amino acids by photosynthetic organisms. Proc Natl Acad Sci 47:623-632

Blanke C, Chikaraishi Y, Vander Zanden MJ (2018) Historical niche partitioning and long-term trophic shifts in Laurentian Great Lakes deepwater Coregonids. Ecosphere 9:e02080

Blanke CM, Chikaraishi Y, Takizawa Y, Steffan SA, Dharampal PS, Vander Zanden MJ (2017) Comparing compound-specific and bulk stable nitrogen isotope trophic discrimination factors across multiple freshwater fish species and diets. Can J Fish Aquat Sci 74:1291-1297

Broek TAB, McCarthy MD (2015) A new approach to $\delta^{15} \mathrm{~N}$ compound-specific amino acid trophic position measurements: preparative high pressure lipid chromatography technique for purifying under derivatized amino acids for stable isotope analysis. Limnol Oceanogr Methods 12:840-852

Carreon-Martinez L, Heath DD (2010) Revolution in food web analysis and trophic ecology: diet analysis by DNA and stable isotope analysis. Mol Ecol 19:25-27

Chikaraishi $\mathrm{Y}(2014){ }^{13} \mathrm{C} /{ }^{12} \mathrm{C}$ signatures in plants and algae. In: Falkowski $\mathrm{PG}$ Freeman $\mathrm{KH}$ (eds) Treatise on geochemistry 2nd edition, Volume 12, Amsterdam, pp 95-123

Chikaraishi Y, Kashiyama Y, Ogawa NO, Kitazato H, Ohkouchi N (2007) Biosynthetic and metabolic controls of nitrogen isotopic composition of amino acids in marine macroalgae and gastropods: implications for aquatic food web studies. Mar Ecol Prog Ser 342:85-90

Chikaraishi Y, Ogawa NO, Kashiyama Y, Takano Y, Suga H, Tomitani A, Miyashita H, Kitazato H, Ohkouchi N (2009) Determination of aquatic food-web structure based on compound-specific nitrogen isotopic composition of amino acids. Limnol Oceanogr Methods 7:740-750

Chikaraishi Y, Ogawa NO, Ohkouchi N (2010b) Further evaluation of the trophic level estimation based on nitrogen isotopic composition of amino acids. In: Ohkouchi N, Tayasu I, Koba K (eds) Earth, Life, and Isotopes. Kyoto University Press, Kyoto, pp 37-51

Chikaraishi Y, Ohkouchi N (2010) An improved method for precise determination of carbon isotopic composition of amino acids. In: Ohkouchi N, Tayasu I, Koba K (eds) Earth, Life, and Isotopes. Kyoto University Press, Kyoto, pp 355366

Chikaraishi Y, Steffan SA, Ogawa NO, Ishikawa Fl, Sasaki Y, Tsuchiya M, Ohkouchi N (2014) High-resolution food webs based on nitrogen isotopic composition of amino acids. Ecol Evol 4:2423-2449

Chikaraishi Y, Steffan SA, Takano Y, Ohkouchi N (2015) Diet quality influences isotopic discrimination among amino acids in an aquatic vertebrate. Ecol Evol 5:2048-2059

Chikaraishi Y, Takano Y, Ogawa NO, Ohkouchi N (2010a) Instrumental optimization for compound-specific nitrogen isotope analysis of amino acids by gas chromatography/combustion/isotope ratio mass spectrometry. In: Ohkouchi N, Tayasu I, Koba K (eds) Earth, Life, and Isotopes. Kyoto University Press, Kyoto, pp 367-386

Choi B, Ha S-Y, Lee J-S, Chikaraishi Y, Ohkouchi N, Shin K-H (2017) Trophic interaction among organisms in a seagrass meadow ecosystem as revealed by bulk $\delta^{13} \mathrm{C}$ and amino acid $\delta^{15} \mathrm{~N}$ analyses. Limnol Oceanogr 62:1426-1435

Choi B, Takizawa Y, Chikaraishi Y (2018) Compression of trophic discrimination in ${ }^{15} \mathrm{~N} /{ }^{14} \mathrm{~N}$ within amino acids for herbivorous gastropods. Res Organic Geochem 34:29-35

Choy CA, Popp BN, Hannides CCS, Drazen JC (2015) Trophic structure and food resources of epipelagic and mesopelagic fishes in the North Pacific Subtropical Gyre ecosystem inferred from nitrogen isotopic compositions. Limnol Oceanogr 60:1156-1171

Choy K, Nash SH, Kristal AR, Hopkins S, Boyer BB, O'Brien M (2013) The carbon isotope ratio of alanine in red blood cells is a new candidate biomarker of sugar-sweetened beverage intake. J Nutr 143:878-884

Corr LT, Berstan R, Evershed RP (2007a) Optimisation of derivatisation procedures for the determination of $\delta^{13} \mathrm{C}$ values of amino acids by gas chromatography/ combustion/isotope ratio mass spectrometry. Rapid Commun Mass Spectrom 21:3759-3771 
Corr LT, Berstan R, Evershed RP (2007b) Development of N-acetyl methyl ester derivatives for the determination of $\delta^{13} \mathrm{C}$ values of amino acids using gas chromatography-combustion-isotope ratio mass spectrometry. Anal Chem 79:9082-9090

Demmelmair H, Schmidt H-L (1993) Precise $\delta^{13} \mathrm{C}$-determination in the range of natural abundance on amino acids from protein hydrolysates by gas chromatography - isotope ratio mass spectrometry. Isot Environ Health Stud 29:237-250

DeNiro MJ, Epstein S (1977) Mechanism of carbon isotope fractionation associated with lipid synthesis. Science 197:261-263

Dharampal PS, Findlay RH (2017) Mercury levels in largemouth bass (Micropterus salmpides) from regulate and unregulated rivers. Chemosphere 170:134-170

Docherty G, Jones V, Evershed RP (2001) Practical and theoretical considerations in the gas chromatography/combustion/isotope ratio mass spectrometry $\delta^{13} \mathrm{C}$ analysis of small polyfunctional compounds. Rapid Commun Mass Spectrom 15:730-738

Dunn PJH, Honch NV, Evershed RP (2011) Comparison of liquid chromatographyisotope ratio mass spectrometry (LC/RMS) and gas chromatographycombustion-isotope ratio mass spectrometry (GC/C/RMS) for the determination of collagen amino acid $\delta^{13} \mathrm{C}$ values for palaeodietary and palaeoecological reconstruction. Rapid Commun Mass Spectrom 25:29953011

Engel MH, Macko SA, Silfer JA (1990) Carbon isotope composition of individual amino acids in the Murchison meteorite. Nature 348:47-49

Fantle MS, Dittel Al, Schwalm SM, Epifanio CE, Fogel ML (1999) A food web analysis of the juvenile blue crab, Callinectes sapidus, using stable isotopes in whole animals and individual amino acids. Oecologica 120:416-426

Fry B (2006) Stable isotope ecology. Springer, New York

Fry B, Carter JF, Yamada K, Yoshida N, Juchelka D (2018) Position-specific ${ }^{13} \mathrm{C} /{ }^{12} \mathrm{C}$ analysis of amino acid carboxyl groups - automated flow-injection analysis based on reaction with ninhydrin. Rapid Commun Mass Spectrom 32:992-1000

Gaebler OH, Choitz HC, Vitti TG, Vukmirovich R (1963) Significance of ${ }^{15} \mathrm{~N}$ excess in nitrogenous compounds of biological origin. Can J Biochem Physiol 41: 1089-1097

Gaebler OH, Vitti TG, Vukmirovich R (1966) Isotope effects in metabolism of ${ }^{14} \mathrm{~N}$ and ${ }^{15} \mathrm{~N}$ from unlabeled dietary proteins. Can J Biochem Physiol 44:1249-1275

Germain LR, Koch PL, Harvey J, McCarthy MD (2013) Nitrogen isotope fractionation in amino acids from harbor seals: implications for compoundspecific trophic position calculations. Mar Ecol Prog Ser 482:265-277

Goto AS, Miura K, Korenaga T, Hasegawa T, Ohkouchi N, Chikaraishi Y (2018) Fractionation of stable nitrogen isotopes $\left({ }^{15} \mathrm{~N} /{ }^{14} \mathrm{~N}\right)$ during enzymatic deamination of glutamic acid: Implications for mass and energy transfers in the biosphere. Geochem J 52:273-280

Hare PE, Fogel ML, Stafford TW Jr, Mitchell AD, Hoering TC (1991) The isotopic composition of carbon and nitrogen in individual amino acids isolated from modern and fossil proteins. J Archaeol Sci 18:211-292

Hayes JM (2001) Fractionation of carbon and hydrogen isotopes in biosynthetic processes. In: Valley JW, Cole DR (eds) Reviews in Mineralogy and Geochemistry 43, Stable Isotope Geochemistry. The Mineralogical Society of America, Washington, pp 225-277

Hoering T (1957) The isotopic composition of the ammonia and the nitrate ion in rain. Geochim Cosmochim Acta 12:97-102

Howland MR, Corr LT, Young SMM, Jones V, Jim S, Van Der Merwe NJ, Mitchell $A D$, Evershed RP (2003) Expression of the dietary isotope signal in the compound-specific $\delta^{13} \mathrm{C}$ values of pig bone lipids and amino acids. Int J Osteoarchaeol 13:54-65

Ishikawa NF (2018) Use of compound-specific nitrogen isotope analysis in trophic ecology: assumptions, applications, and implications. Ecol Res 33:825-837

Khan MR, Khan MR (2002) Mass rearing of Menochilus sexmaculatus Fabricus (Coleoptera: Coccinellidae) on natural and artificial diets. Int J Agric Biol 4 107-109

Larsen T, Bach LT, Salvatteci R, Wang WV, Andersen N, Ventura M, McCarthy MD (2015) Assessing the potential of amino acid ${ }^{13} \mathrm{C}$ patterns as a carbon source tracer in marine sediments: effects of algal growth conditions and sedimentary diagenesis. Biogeoscience 12:4979-4992

Larsen T, Taylor DE, Leigh MB, O'Brien DM (2009) Stable isotope fingerprinting: a novel method for identifying plant, fungal, or bacterial origins of amino acids. Ecology 90:3526-3535

Larsen T, Ventura M, Andersen N, O'Brien DM, Piatkowski U, McCarthy MD (2013) Tracing carbon sources through aquatic and terrestrial food webs using amino acid stable isotope fingerprinting. PLOS ONE 8:e73441
Lorrain AL, Graham BS, Popp BN, Allain V, Olson RJ, Hunt BPV, Potir M, Fry B, Galván-Magaña F, Menkes CER, Kaehler S, Ménard F (2015) Nitrogen isotopic baselines and implications for estimating foraging habitat and trophic position of yellowfin tuna in the Indian and Pacific Oceans. Deep-Sea Res II Top Stud Oceanogr 113:188-198

Macko SA, Fogel ML, Hare PE, Hoering TC (1987) Isotopic fractionation of nitrogen and carbon in the synthesis of amino acids by microorganisms. Chem Geol 65:79-92

Maeda T, Hirose E, Chikaraishi Y, Kawato M, Takishita K, Yoshida T, Verbruggen H, Tanaka J, Shimamura S, Takaki Y, Tsuchiya M, Iwai K, Maruyama T (2012) Algivore or phototroph? Plakobranchus ocellatus (Gastropoda) continuously acquires kleptoplasts and nutrition from multiple algal species in nature. PLOS ONE 7:e42024

Mariotti A, Germon JC, Hubert P, Kaiser P, Letolle R, Tardieux A, Tardieux P (1981) Experimental determination of nitrogen kinetic isotope fractionation: some principles; illustration for the denitrification and nitrification processes. Plant Soil 62:413-430

McCarthy MD, Benner R, Lee C, Fogel ML (2007) Amino acid nitrogen isotopic fractionation patterns as indicators of heterotrophy in plankton, particulate, and dissolved organic matter. Geochim Cosmochim Acta 71:4727-2744

McCarthy MD, Benner R, Lee C, Hedhes Jl, Fogel ML (2004) Amino acid carbon isotopic fractionation patterns in oceanic dissolved organic matter: an unaltered photoautotrophic source for dissolved organic nitrogen in the ocean? Mar Chem 92:123-134

McClelland JW, Montoya JP (2002) Trophic relationships and the nitrogen isotopic composition of amino acids in plankton. Ecology 83:2173-2180

McMahon KW, Fogel ML, Elsdon TS, Thorrold SR (2010) Carbon isotope fractionation of amino acids in fish muscle reflects biosynthesis and isotopic routing from dietary protein. J Anim Ecol 79:1132-1141

McMahon KW, McCarthy MD (2016) Embracing variability in amino acid $\delta^{15} \mathrm{~N}$ fractionation: mechanisms, implications, and applications for trophic ecology. Ecosphere 7:e01511

McMahon KW, Thorrold SR, Elsdon TS, McCarthy MD (2015) Trophic discrimination of nitrogen stable isotopes in amino acids varies with diet quality in a marine fish. Limnol Oceanogr 60:1076-1087

McMahon KW, Thorrold SR, Houghton LA, Berumen ML (2016) Tracing carbon flow through coral reef food webs using a compound-specific stable isotope approach. Oecologia. 180:809-821

Melzer E, Schmidt H-L (1987) Carbon isotope effects on the pyruvate dehydrogenase reaction and their importance for relative carbon-13 depletion in Lipids. J Biol Chem 262:8159-8164

Merritt DA, Hayes JM (1994) Nitrogen isotopic analyses by isotope-ratiomonitoring gas chromatography/mass spectrometry. J Am Soc Mass Spectrom 5:87-397

Metges CC, Daenzer M (2000) ${ }^{13} \mathrm{C}$ gas chromatography-combustion isotope ratio mass spectrometry analysis of $\mathrm{N}$-pivaloyl amino acid esters of tissue and plasma samples. Anal Biochem 278:156-164

Metges CC, Petzke K-J, Hennig U (1996) Gas chromatography/combustion/ isotope ratio mass spectrometric comparison of $\mathrm{N}$-acetyl- and $\mathrm{N}$-pivaloyl amino acid esters to measure ${ }^{15} \mathrm{~N}$ isotopic abundances in physiological samples: a pilot study on amino acid synthesis in the upper gastro-intestinal tract of minipigs. J Mass Spectrom 31:367-376

Monson KD, Hayes JM (1980) Biosynthetic control of the natural abundance of carbon 13 at specific positions within fatty acids in Escherichia coli. J Biol Chem 255:11435-11441

Monson KD, Hayes JM (1982) Carbon isotopic fractionation in the biosynthesis of bacterial fatty acids. Ozonolysis of unsaturated fatty acids as a means of determining the intramolecular distribution of carbon isotopes. Geochim Cosmochim Acta 46:139-149

Morra KE, Chikaraishi Y, Gandhi H, James HF, Rossman S, Wiley AE, Raine AF, Beck J, Ostrom PH (2019) Trophic declines and decadal-scale foraging segregation in three pelagic seabirds. Oecologia 189:395-406

O'Brien DM, Boggs CL, Fogel ML (2005) The amino acids used in reproduction by butterflies: a comparative study of dietary sources using compound-specific stable isotope analysis. Physiol Biochem Zool 78:819-827

O'Brien DM, Fogel ML, Boggs CL (2002) Renewable and nonrenewable resources: Amino acid turnover and allocation to reproduction in Lepidoptera. Proceed Nat Acad Sci 99:4413-4418

Ohkouchi N, Chikaraishi Y, Close HG, Fry B, Larsen T, Madigan DJ, McCarthy MG, McMahon KW, Nagata T, Naito YI, Ogawa NO, Popp BN, Steffan SA, Takano Y, Tayasu I, Wyatt ASJ, Yamaguchi YT, Yokoyama Y (2017) Advances in the 
application of amino acid nitrogen isotopic analysis in ecological and biogeochemical studies. Org Geochem 113:150-174

Ohkouchi N, Ogawa NO, Chikaraishi Y, Tanaka H, Wada E (2015) Biochemical and physiological bases for the use of carbon and nitrogen isotopes in environmental and ecological studies. Prog Earth Planetary Sci 2:1

Ostrom PH, Wiley AE, James HF, Rossman S, Walker WA, Zipkin EF, Chikaraishi Y (2017) Broad-scale trophic shift in the pelagic North Pacific revealed by an oceanic seabird. Proc R Soc B 284:20162436

Ostrom PH, Zonneveld J-P, Robbins LL (1994) Organic geochemistry of hard parts: assessment of isotopic variability and indigeneity. Palaeogeogr Palaeoclimatol Palaeoecol 107:201-212

Popp BN, Graham BS, Olson RJ, Hannides CCS, Lott M, López-Ibarra G, GalvánMagaña F (2007) Insight into the trophic ecology of yellowfin tuna, Thunnus albacares, from compound-specific nitrogen isotope analysis of proteinaceous amino acids. In: Dawson TE, Siegwolf RTW (eds) Stable isotopes as indicators of ecological change. Academic Press, San Diego, pp $173-190$

Rieley G (1994) Derivatization of organic compounds prior to gas chromatographic-combustion-isotope ratio mass spectrometric analysis: identification of isotope fractionation processes. Analyst 199:915-919

Silfer JA, Engel MH, Macko SA, Jumeau EJ (1991) Stable carbon isotope analysis of amino acid enantiomers by conventional isotope ratio mass spectrometry and combined gas chromatography/isotope ratio mass spectrometry. Anal Chem 63:370-374

Smith Cl, Fuller BT, Choy K, Richards MP (2009) A three-phase liquid chromatographic method for $\delta^{13} \mathrm{C}$ analysis of amino acids from biological protein hydrolysates using liquid chromatography-isotope ratio mass spectrometry. Anal Biochem 390:165-172

Steffan SA, Chikaraishi Y, Currie CR, Horn H, Gaines-Day HR, Pauli JN, Zalapa JE, Ohkouchi N (2015) Microbes are trophic analogs of animals. Proc Natl Acad Sci 112:15119-15124

Steffan SA, Chikaraishi Y, Dharampal PS, Pauli JN, Guédot C, Ohkouchi N (2017) Unpacking brown food-webs: animal trophic identity reflects rampant microbivory. Ecol Evol 7:3532-3541

Steffan SA, Chikaraishi Y, Horton DR, Ohkouchi N, Singleton ME, Miliczky E, Hogg DB, Jones VP (2013) Trophic hierarchies illuminated via amino acid isotopic analysis. PLOS ONE 8:e76152

Takano Y, Chikaraishi Y, Imachi H, Miyairi Y, Ogawa NO, Kaneko M, Yokoyama Y, Krüger M, Ohkouchi N (2018) Insight into anaerobic methanotrophy from

${ }^{13} \mathrm{C} /{ }^{12} \mathrm{C}$ - amino acids and ${ }^{14} \mathrm{C} /{ }^{12} \mathrm{C}$-ANME cells in seafloor microbial ecology. Sci Rep 8:14070

Takizawa Y, Chikaraishi Y (2014) Are baby sprouts eating the proteins in the mother sweet potato? Res Organic Geochem 30:29-32

Takizawa Y, Chikaraishi Y (2017) Change in the $\delta^{15} \mathrm{~N}$ value of plant amino acids on the phenology of leaf flush and senescence. Res Organic Geochem 33:1-6

Takizawa Y, Dharampal PS, Steffan SA, Takano Y, Ohkouchi N, Chikaraishi Y (2017) Intra-trophic isotopic discrimination of ${ }^{15} \mathrm{~N} /{ }^{14} \mathrm{~N}$ for amino acids in autotrophs: implication for nitrogen dynamics in ecological studies. Ecol Evol 7:2916-2924

Traugott M, Kamenova S, Ruess L, Seeber J, Plantegenest M (2013) Empirically characterising trophic networks: what emerging DNA based methods, stable isotope and fatty acid analyses can offer. Adv Ecol Res 49:177-224

Wada E, Ishii R, Aita MN, Ogawa NO, Kohzu A, Hyodo F, Yamada Y (2013) Possible ideas on carbon and nitrogen trophic fractionation of food chains: a new aspect of food-chain stable isotope analysis in Lake Biwa, Lake Baikal, and the Mongolian grasslands. Ecol Res 28:173-181

Watanabe M, Owada M, Kanazawa K (2009) Dietary habits of doridacean sea slugs of the Sagami Bay. Sci J Kanagawa Univ 20:85-88

\section{Publisher's Note}

Springer Nature remains neutral with regard to jurisdictional claims in published maps and institutional affiliations. 